\title{
Bed erosion during fast ice streaming regulated the retreat dynamics of
} the Irish Sea Ice Stream.

Van Landeghem, Katrien; Chiverrell, Richard

\section{Quaternary Science Reviews}

DOI:

10.1016/j.quascirev.2020.106526

Published: 01/10/2020

Peer reviewed version

Cyswllt i'r cyhoeddiad / Link to publication

Dyfyniad o'r fersiwn a gyhoeddwyd / Citation for published version (APA):

Van Landeghem, K., \& Chiverrell, R. (2020). Bed erosion during fast ice streaming regulated the retreat dynamics of the Irish Sea Ice Stream. Quaternary Science Reviews, 245, [106526]. https://doi.org/10.1016/j.quascirev.2020.106526

\footnotetext{
Hawliau Cyffredinol / General rights

Copyright and moral rights for the publications made accessible in the public portal are retained by the authors and/or other copyright owners and it is a condition of accessing publications that users recognise and abide by the legal requirements associated with these rights.

- Users may download and print one copy of any publication from the public portal for the purpose of private study or research.

- You may not further distribute the material or use it for any profit-making activity or commercial gain

- You may freely distribute the URL identifying the publication in the public portal ?
}

Take down policy

If you believe that this document breaches copyright please contact us providing details, and we will remove access to the work immediately and investigate your claim. 


\section{Bed erosion during fast ice streaming regulated the retreat}

\section{2 dynamics of the Irish Sea Ice Stream.}

\section{Katrien J. J. Van Landeghem ${ }^{1}$ and Richard C. Chiverrell ${ }^{2}$}

$4{ }^{1}$ School of Ocean Sciences, Bangor University, Menai Bridge, LL59 5AB, UK

$5 \quad{ }^{2}$ School of Environmental Sciences, University of Liverpool, Liverpool, L69 7ZT, UK

\section{ABSTRACT}

7 Marine-terminating ice stream behaviour often defines the stability of ice sheets and is driven

8 by a complex interplay of climatic, oceanic, topographic and glaciological factors. Here, we

9 use new integrated high resolution, extensive $\left(2100 \mathrm{~km}^{2}\right)$ and continuous geophysical,

10 sedimentological and geotechnical data to reconstruct past glacial environments during the

11 Last Glacial Maximum from a well-preserved palaeo-landscape. The data is from the axial centre of the Irish Sea Ice Stream (ISIS), which drained $>17 \%$ of the former British-Irish Ice Sheet. Recent geochronological data of the palaeo-ISIS show a build-up and advance of ice to marine-terminating maximum limits in the southern Celtic Sea 27-25 ka BP, followed by rapid ice margin retreat into the northern Irish Sea Basin (ISB) by $20.8 \pm 0.7 \mathrm{ka} \mathrm{BP}$. However, the flow dynamics in the central and axial bed of the ISIS through this timeframe are not well understood. Here, we use our new glacial landscape reconstruction to identify the spatial and temporal patterns of flow re-organisation and re-activations for the marineterminating ISIS. From this we infer how ice streaming was driven by a variety of factors through advance, deglaciation and towards a temporary lift-off of ice from its bed and an ultimate demise. Overprinted subglacial bedforms with differing ice flow directions indicate an on/off behaviour to the ice-streaming, an increasing topographical influence and substantial realignment of ice flows. Subsurface geophysical data reveal the erosive 
capability of the ice stream through time, with a first erosive component in the formation of mega-scale glacial lineations leaving bedrock exposed at the ice stream bed. The depositional component of MSGL crest building occurred in the same ice-flow phase. Whilst the ice stream was laterally constricted in two locations, likely contributing to changes in ice margin retreat rates, we also propose that changes in basal drag associated with exposed bedrock at the ice-bed interface influenced the retreat dynamics, particularly when this exposure was near the grounding zone. The wider implications of this work are that episodic and highly erosive ice streaming during ice advance and early retreat can change ice-bed conditions radically and in turn influence glacial dynamics during later retreat episode, thus constituting a feedback process to be considered in modelling the dynamics of marine-terminating ice streams.

\section{KEYWORDS}

Quaternary; Glaciology (incl. palaeo-ice sheets); Europe; Geomorphology, glacial; Geophysics; Subglacial Bedforms; British-Irish Ice Sheet; Palaeo-ice streaming; Deglaciation

\section{INTRODUCTION}

\subsection{Grounded ice stream dynamics and aim of the study}

Deglaciation patterns of major ice sheets are determined by responses to climatic and oceanographic changes (external forcing), topographic and basal thermal conditions (internal forcing), with margin retreat rates varying by as much as an order of magnitude (Stroeven et al., 2016). Ice streams are conduits of grounded ice flowing faster than adjacent areas (Paterson, 1994) and account for most of the ice discharge in Antarctica (Bamber et al., 2000). Realistic ice sheet drainage simulations therefore require knowledge of the onset of, variations in, and shut-down of ice streaming (Jamieson et al., 2012; Schoof and Hewitt, 
2016). The former Irish Sea Ice Stream (ISIS) drained $>17 \%$ of the former British-Irish Ice Sheet (BIIS). During the last deglaciation (25-18 ka BP) the ISIS experienced fluctuations between rapid retreat (in the range 100-550 $\mathrm{m} \mathrm{a}^{-1}$ ), stabilisation and short-lived re-advances of the ice margins (Chiverrell et al., 2018; Praeg et al., 2015; Scourse et al., 2019; Small et al., 2018; Smedley et al., 2017a; Smedley et al., 2017b). Whilst the ice margin chronology of ISIS is constrained well, no high-resolution shallow sub-seafloor information of the central part of the ice flow conduit, the Irish Sea Basin (ISB - see Fig. 1) has thus far been integrated to understand consecutive flow phases. We have only small snapshots of one preserved surface of the former ice bed to inform us of the ice dynamical processes associated with the ice margin fluctuations. On the seafloor NW of Anglesey, grounded ice streaming is evidenced, and numerous iceberg scours show that retreat of the ISIS was in part accompanied by a calving ice margin (Van Landeghem et al., 2009). New and extensive data are provided here for both the surface and subsurface of the central sector of the ISB (see Fig. 1), making it an ideal testing ground for exploring subglacial evidence for changes in ice stream dynamics during the well-dated advance, retreat and ultimate demise in the period of $27-18 \mathrm{ka} \mathrm{BP}$.

Grounded marine margins can become unstable influencing ice sheet mass flux and rates of deglaciation, with bed topography, subglacial bed properties and meltwater processes as first order controls (Kleman and Applegate, 2014; Rignot et al., 2014; Bradwell et al., 2019). For the former ISIS a high amplitude tidal regime and rising relative sea-levels (Bradley et al., 2011; Ward et al., 2016) are further factors affecting potentially the stability of the ice margin. Observations of ice streams in the palaeo-domain can provide a longer temporal range and more extensive spatial perspective to that available typically in the observational ice stream record. For example, Lakeman et al. (2018) used geophysical, stratigraphical and chronological data in the western Canadian Arctic to reconstruct a $250 \mathrm{~km}$ retreat of a 
marine-terminating ice stream in $~ 250$ years during the Younger Dryas. Direct comparison of

74 bedforms observed developing at contemporary ice stream beds with equivalent bedforms

75 from palaeo-ice streams, provides basis for interpretation of deglacial processes (Van

76 Landeghem et al., 2009) and surge-stagnation-reactivation cycles (Kurjanski et al., 2019).

77 Observations of how ice-bed interfaces have evolved through time can be discerned from

78 information on (sub-)seabed geophysical surveys (see reviews in Stokes, 2018) and provide

79 potentially important constraint for simulations of glacial dynamics (Hindmarsh, 2018).

80
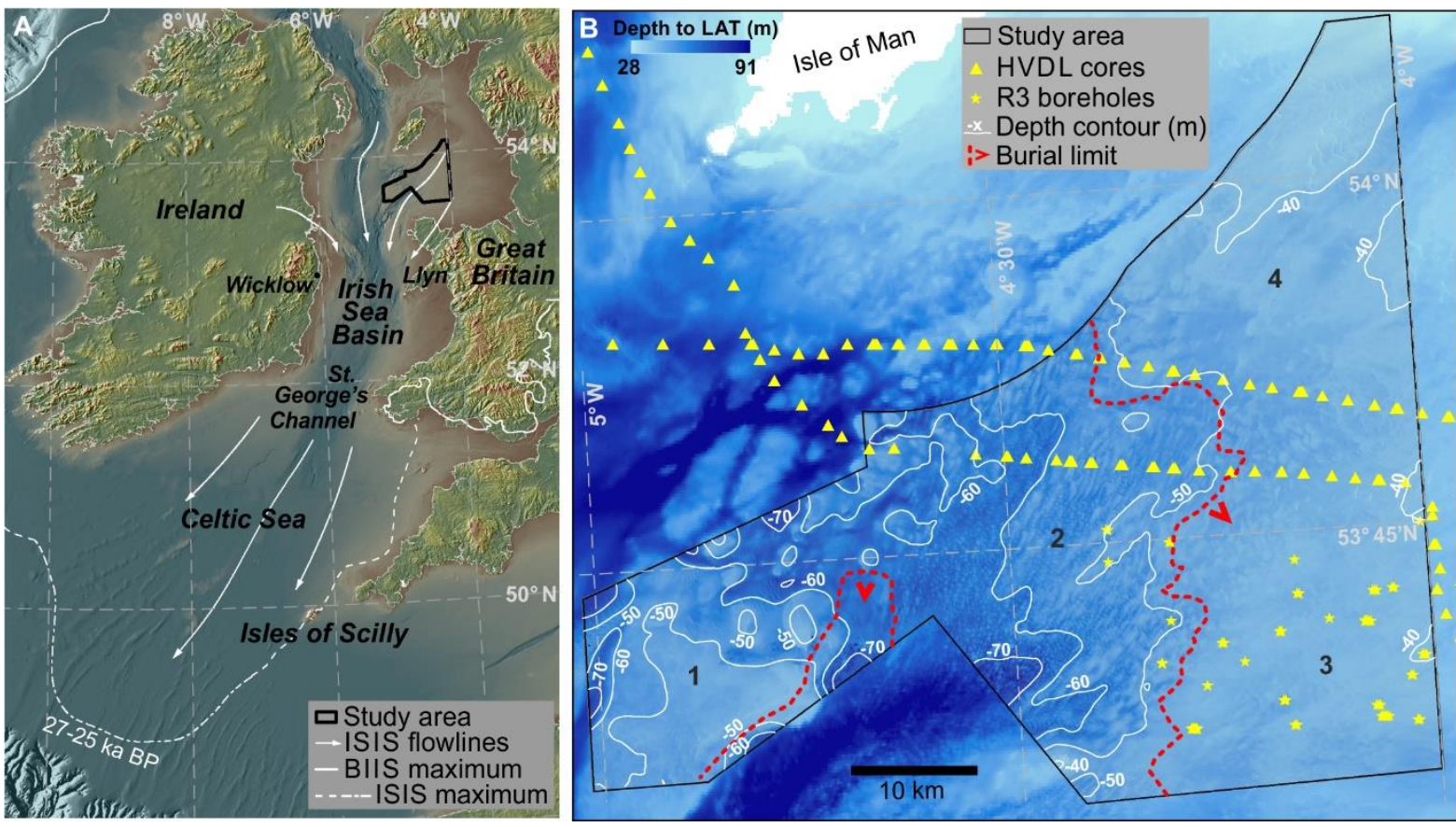

82 Figure 1. Panel (A) shows the Irish Sea Basin (ISB) with indicative Irish Sea Ice Stream

83 (ISIS) flow lines and the maximum extent of the British-Irish Ice Sheet and ISIS at ca. 27-25

84 ka BP (Chiverrell et al., 2013; Praeg et al., 2015). Panel (B) shows the study area divided in 4 zones: (Zone 1) a western till plateau, (Zone 2) subglacial bedforms, (Zone 3) buried subglacial bedforms, and (Zone 4) an eastern till plateau. The extent of the geophysical and sedimentological data collected in preparation of a Round 3 (R3) Windfarm development 
project is displayed, as are the High Voltage Direct Link (HVDL) cable installation cores.

Depth to seafloor is relative to the Lowest Astronomical Tide (LAT).

91 The aim of this study is to use reconstructed ISIS dynamics as a case study to explain the processes behind changes in ice stream advance, retreat and fluctuations in relation to geological factors of the subglacial bed. We achieve this by reconstructing the temporal and spatial evolution of a palaeo-glacial landscape for the axial central sector of the ice stream (Fig. 1A), contextualised by the palaeo-ISIS geochronology during the Last Glacial Maximum (27-18 ka BP - see next section). A new $2100 \mathrm{~km}^{2}$ seabed geophysical and sedimentological dataset is analysed to capture evidence of changing topography, sediment distribution and glacial bedform assemblages from which we interpret changes in thermal regime, bed topography, bed roughness, drainage patterns, ice flow direction and velocity for the axial sector of the ISIS.

\subsection{The palaeo-ISIS geochronology}

The time series for grounded ice margin dynamics in this area is divided here into five stages. The maximum extension of grounded ice reached the Celtic Sea shelf break around 27-25 ka BP (Stage 1) (Praeg et al., 2015; Scourse et al., 2019; Smedley et al., 2017b). It then had retreated rapidly by $400 \mathrm{~km}$ to the south coast of Ireland at $25.1 \pm 1.2 \mathrm{ka} \mathrm{BP}$ (Stage 2), eventually stabilizing at the constriction of the St-George's Channel at $24.2 \pm 1.2 \mathrm{ka} \mathrm{BP}$

107 (Small et al., 2018). The Irish Ice Sheet may have advanced into the Celtic Sea again (Tótz et

108 al., 2020), but the margin of the Irish Sea Ice Stream retreated rapidly towards the

109 constriction between Wicklow - Llŷn Peninsula at 22.6 \pm 1 ka BP, where it stabilised (Stage

110 3) (Small et al., 2018; Smedley et al., 2017a). The western and deeper (100-140 m below

111 mean sea level (bmsl)) ISB had deglaciated by $19.8 \pm 0.8$ ka BP (Ballantyne and Ó Cofaigh, 
112 2017; McCabe, 2008), whereas the retreat of ice margins in the adjacent shallower (50-20 m

113 bmsl) eastern ISB was slower crossing and moving north of the Isle of Man from $20.7 \pm 0.7$

114 and $19.3 \pm 0.8 \mathrm{ka} \mathrm{BP}$ onwards (Stage 4) (Chiverrell et al., 2018). Stage 5 (between $19.3 \pm 0.8$

115 ka and $18.3 \pm 1.1 \mathrm{ka} \mathrm{BP}$ ) represents an ice-free study area, but a re-advance of Scottish ice on

116 the northern edge of the Isle of Man after $18.3 \pm 1.1 \mathrm{ka} \mathrm{BP}$ may have seen ice encroach on the

117 area (Chiverrell et al., 2018).

118 1.3. Glacial bedforms in palaeo-environmental reconstructions

119 The type of glacial bedform can be indicative of cold- or warm-based basal conditions

120 (Kleman and Glasser, 2007; Kleman et al., 2006) whilst bedform geometry can reflect

121 changes in ice flow direction and relative changes in velocity (King et al., 2009; Landvik et

122 al., 2014; Stokes and Clark, 2002). Cold-based ice is below the pressure melting point with

123 no water available at the bed and has a limited ability to transport subglacial sediment and to

124 erode its bed. Thus cold-based ice is mainly associated with preservation of the pre-existing

125 land surface (Cuffey et al., 2000; Paterson, 1994). Warm-based ice is at the pressure melting

126 point with water available at the bed, and therefore associated with more intensive and

127 widespread erosion, deposition and reshaping of the subglacial bed (Kleman and Glasser,

128 2007; Paterson, 1994). Interpreting ice flow direction and velocity from subglacial bedforms

129 has contributed towards a better understanding of the basal thermal organisation and temporal

130 changes in flow regime for former ice streams (for example: Hogan et al., 2010).

\section{2. METHODS}

133 Our reconstruction of changing flow dynamics that characterised the collapsing ISIS stems

134 from new, extensive and high resolution geophysical and geotechnical evidence that

135 document a time and space continuum of an exceptionally preserved glacial landscape. The 
evidence comprises the surface (multibeam data) and sub-surface (acoustic and geotechnical

137 data) expression of an assemblage of glacial bedforms. Acoustic, geotechnical and

138 sedimentological datasets were obtained for Celtic Array LTD for a proposed Round 3 (R3)

139 offshore wind development (Fig. 1B). From this integration of the geomorphological, sub-

140 bottom acoustic, sedimentological and sediment geotechnical evidence, we have mapped a

141 series of glacial bedform assemblages using ESRI ArcGIS software.

\section{$142 \quad$ 2.1. Acoustic surveys}

143 The acoustic data were acquired by the Swedish surveying company MMT (Summer 2010).

144 Bathymetric data were collected with a ship-born Kongsberg EM3002 Multibeam

145 Echosounder (MBES) and processed with CARIS HIPS by MMT. The EM3002 system uses

146 frequencies in the $300 \mathrm{kHz}$ band, ideal for the shallow waters in this area of the Irish Sea (28-

$14792 \mathrm{~m}$ ). The pulse length emitted by the EM3002 transducer is $150 \mu$ s and the depth resolution

148 is $10 \mathrm{~mm}$. Vessel positioning and orientation systems achieved a vertical accuracy $<5 \mathrm{~cm}$

149 and a horizontal accuracy $<0.1 \mathrm{~m}$. The bathymetric data were reduced to Lowest

150 Astronomical Tide (LAT), corrected with the UK Hydrographic Office Vertical Offshore

151 Reference Frame (VORF) model and gridded at $2 \times 2 \mathrm{~m}$. A total of circa $16500 \mathrm{~km}$ of sub-

152 bottom seismic data were collected using a 1kJ GeoSpark 200 tip Sparker source and a Chirp

153 Edgetech $512 \mathrm{i}(0.5-12 \mathrm{kHz})$ in a dense 2-dimensional grid at line spacings of $150 \mathrm{~m}$ and 500

$154 \mathrm{~m}$ for cross-lines, all visualised with the KingdomSuite software package. This provided

155 shallow sub-bottom information with a vertical resolution up to $30 \mathrm{~cm}$, from which bedrock

156 horizons and the top of over-consolidated tills were interpreted and digitised initially by

157 MMT. After a thorough review of the data analyses, the geophysical data outputs were

158 analysed further in ArcGIS. A multi-directional hillshading was applied to the bathymetric

159 grids, reducing a potential directional bias in bedform detection. Focal statistics were

160 performed on the irregular bathymetric surfaces to visualise the background break in slope, 
whereby the mean bathymetric values were calculated in a raster with $500 \mathrm{~m}$ cell size and contour lines smoothened to eliminate the influence of the slope of smaller bedforms.

\subsection{Geotechnical and sedimentological surveys}

164 Seabed drilling was performed by Fugro Survey. The seabed drilling frame was positioned

165 using ultra-short baseline (USBL) acoustics with respect to Fugro's Starfix global positioning

166 system. Additional sediment descriptions were performed by Reynolds International Ltd. and

167 Parsons Brinckerhoff delivered a geotechnical interpretative report. These results were

168 integrated with other borehole surveys (Fig. 1B;2) and the gridded seismic analyses to gain

169 confidence in the stratigraphic interpretations. Normally consolidated sand was generally

170 described as very loose to loose, slightly silty to silty gravelly fine to coarse sand, normally

171 consolidated clay as very soft to stiff slightly sandy slightly gravelly clay. Over-consolidated

172 sand was generally described as dense to very dense slightly silty to silty, gravelly fine to

173 medium sand. Band of gravels and cobbles and closely spaced thin laminae of clay have been

174 recorded in this unit. Over-consolidated clay was generally described as very stiff to very

175 hard slightly sandy to sandy, slightly gravelly clay. Soft bands occur within this unit.

176 Occasional soft bands and sand pockets are recorded within this unit, and a possible boulder.

177 Values for the key geotechnical parameters in Table 1, based on the Recommended Practice 178 for Statistical Representation of Soil Data (DNV, 2007), allowed normally consolidated and

179 over-consolidated sediments to be distinguished from soil profiles, and integrated with

180 seismic sub-bottom profiles. The thickness of the over-consolidated till (Fig. 4; 6; 8) was

181 derived from subtracting Two-Way-Travel Times (TWT) from sound waves reflecting off the

182 top of the bedrock with the TWT from sound waves reflecting off the top of the over-

183 consolidated till (Fig. 6). The speed of sound through the sediments is variable (for example

184 1700-2700 $\mathrm{ms}^{-1}$ measured for clay) and conversion from TWT to meters can only be 185 estimated. 


\begin{tabular}{|c|c|c|c|c|c|}
\hline Parameter & Profile & $\begin{array}{c}\text { Normally } \\
\text { consolidated } \\
\text { clay }\end{array}$ & $\begin{array}{c}\text { Normally } \\
\text { consolidated } \\
\text { sand }\end{array}$ & $\begin{array}{c}\text { Over- } \\
\text { consolidated } \\
\text { clay }\end{array}$ & $\begin{array}{c}\text { Over- } \\
\text { consolidated } \\
\text { sand }\end{array}$ \\
\hline \multirow{2}{*}{$\begin{array}{c}\text { Relative } \\
\text { density } \\
(\%)\end{array}$} & $\begin{array}{l}\text { characteristic } \\
\text { lower bound }\end{array}$ & & 7 & & 40 \\
\hline & $\begin{array}{c}\text { characteristic } \\
\text { mean }\end{array}$ & & 65 & & 85 \\
\hline \multirow{2}{*}{$\begin{array}{l}\text { Undrained } \\
\text { shear } \\
\text { strength } \\
\text { (kPa) }\end{array}$} & $\begin{array}{l}\text { characteristic } \\
\text { lower bound }\end{array}$ & 10 & & 50 & \\
\hline & $\begin{array}{c}\text { characteristic } \\
\text { mean }\end{array}$ & 50 & & 300 & \\
\hline \multirow{2}{*}{$\begin{array}{l}\text { CPT tip } \\
\text { resistance } \\
(\mathrm{MPa})\end{array}$} & $\begin{array}{l}\text { characteristic } \\
\text { lower bound }\end{array}$ & 0.3 & 2 & 4 & 5 \\
\hline & $\begin{array}{c}\text { characteristic } \\
\text { mean }\end{array}$ & 1.2 & 15 & 10 & 30 \\
\hline
\end{tabular}

187 Table 1. Values for the key parameter for the normally and over-consolidated sediments,

188 measured and reported on by Parsons Brinckerhoff.

\section{OBSERVATIONS AND INTERPRETATIONS}

\subsection{Stratigraphic units underpinning interpretation of the glacial landscape.}

192 The stratigraphy of the sub-surface can be summarised as normally consolidated sediments,

193 over-consolidated sediments and bedrock, and these divisions underpin the interpretations of 
194 the glacial landscape. Boreholes (BH) 32a and 33 are representative of this simplified

195 lithostratigraphy. They were recovered along a sub-bottom profile with lateral variation in

196 acoustic properties, and the integration of borehole descriptions and sub-bottom profile is

197 presented in Fig. 2, taking $1800 \mathrm{~ms}^{-1}$ as the speed of sound through the sediments to match

198 the down-core depth in meters to two-way travel time in milliseconds. BH32a was extracted

199 exactly on the sub-bottom profile line. The down-core transition between over-consolidated

200 sediments and the underlying mudstone corresponds with the high-amplitude seismic

201 reflector between chaotic acoustic facies with discontinuous internal reflections, and the

202 acoustic facies underneath with continuous internal reflections at a high angle and the upper

203 boundary reflection forming a sharp angular unconformity. BH33 is offset by $100 \mathrm{~m}$ from the

204 sub-bottom profile line, yet the transition between the normally consolidated sediments at the

205 top and the over-consolidated sediments underneath coincides with a clear distinction

206 between low-medium amplitude acoustic facies and high-amplitude acoustic facies

207 underneath. The transition to bedrock underneath is offset by circa three meters. 


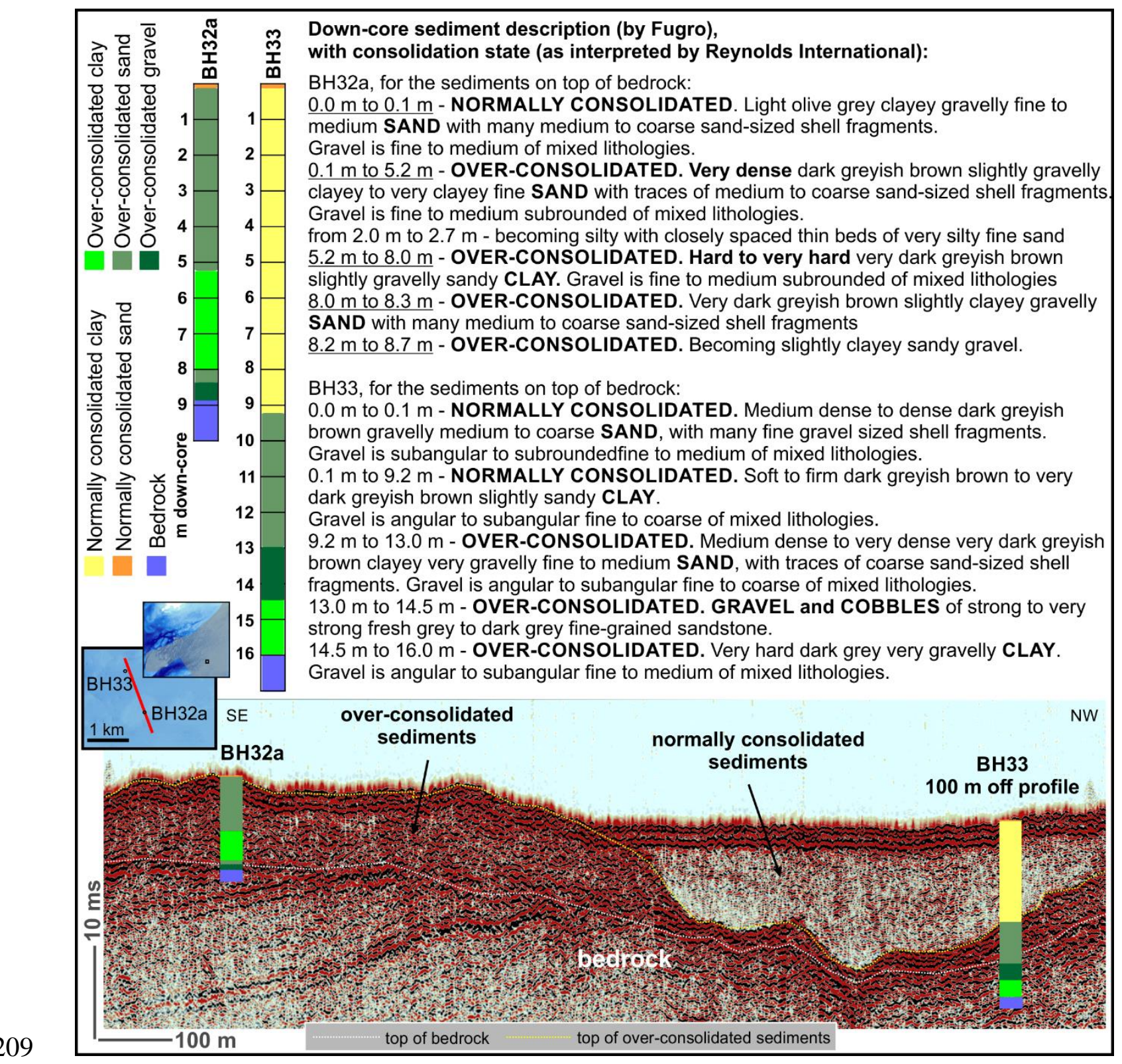

210 Figure 2. Integration of the sedimentological description of two boreholes with the sub-

211 bottom acoustic profile along which they were extracted.

\section{$213 \quad 3.2$ Mapping the glacial landscape with inferred ice flow directions}

214 The bedform record in this study area is dominated by glacial bedforms. These bedforms

215 were mapped on both the seabed surface and in the sub-surface. With locations of examples

216 presented in Fig. 3., Fig. 4 summarises in three page-wide panels the interpretive lexicon used 
217 for the glacial bedforms analysed in this area. From their geomorphological and spatial

218 analyses, it was possible to reconstruct the patterns of ice flow and to infer the changing

219 properties in subglacial bed conditions in the centre of the ISB. To assess wavelengths in

220 between flat topped subglacial bedforms, it was more accurate to delineate the trough in

221 between the bedforms, which had a steeper dip and could be better observed and delineated.

222 Groupings of glacial bedforms with typically a spatial extent $>50 \mathrm{~km}^{2}$ and a coherence in

223 terms of morphology, proximity and orientation are used here to identify a series of ice-flow

224 sets. To facilitate discussion of the bedform sequence, the glacial landscape is subdivided into

225 four broad morphological regions (Fig. 1B): (Zone 1) a western till plateau, (Zone 2)

226 subglacial bedforms, (Zone 3) buried subglacial bedforms, and (Zone 4) an eastern till

227 plateau.

228

229

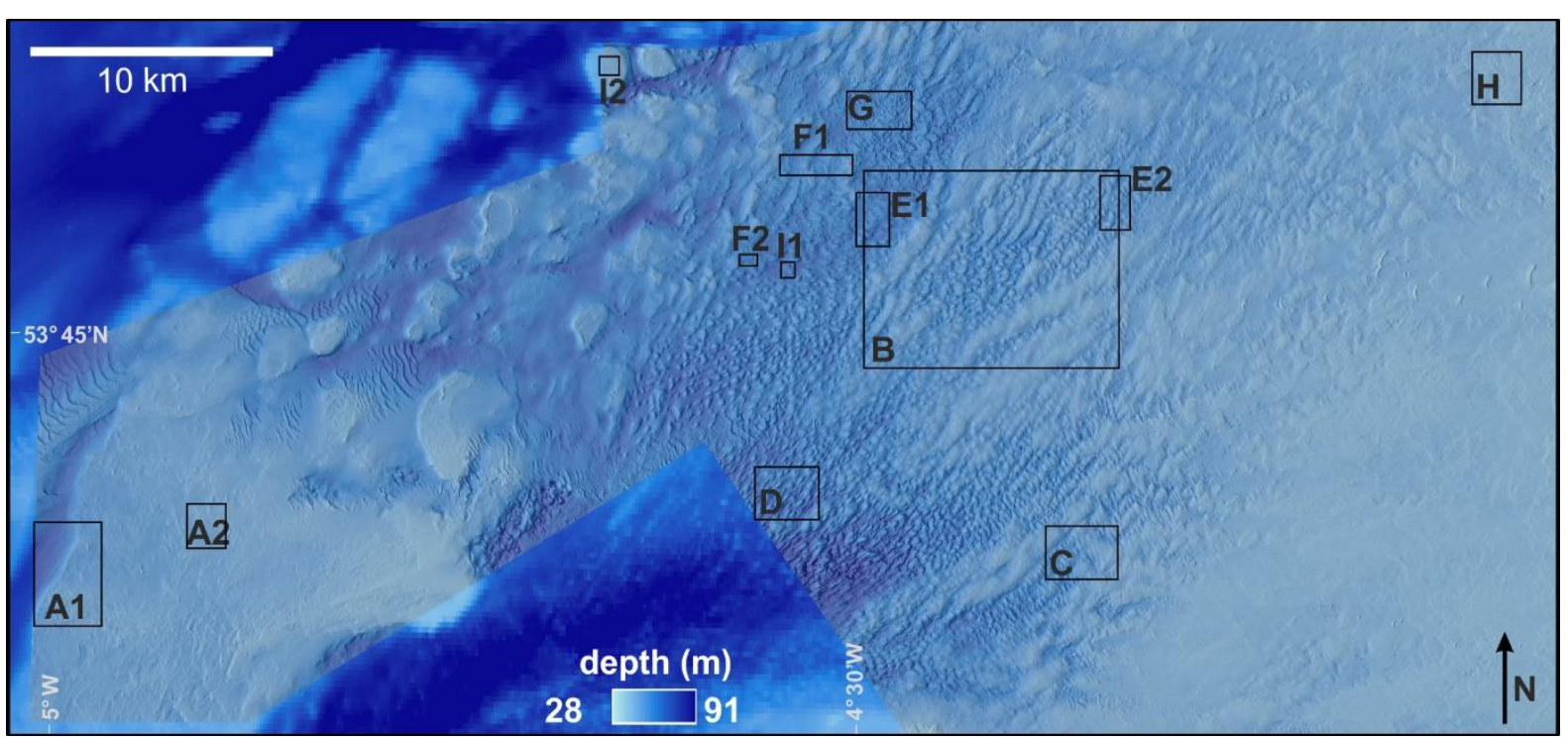

230 Figure 3: Seabed bathymetry of study area illuminated with multi-directional hillshading,

231 identifying the location of exemplar bedforms presented in Fig. 4, where individual glacial

232 bedforms are shown and analysed. 


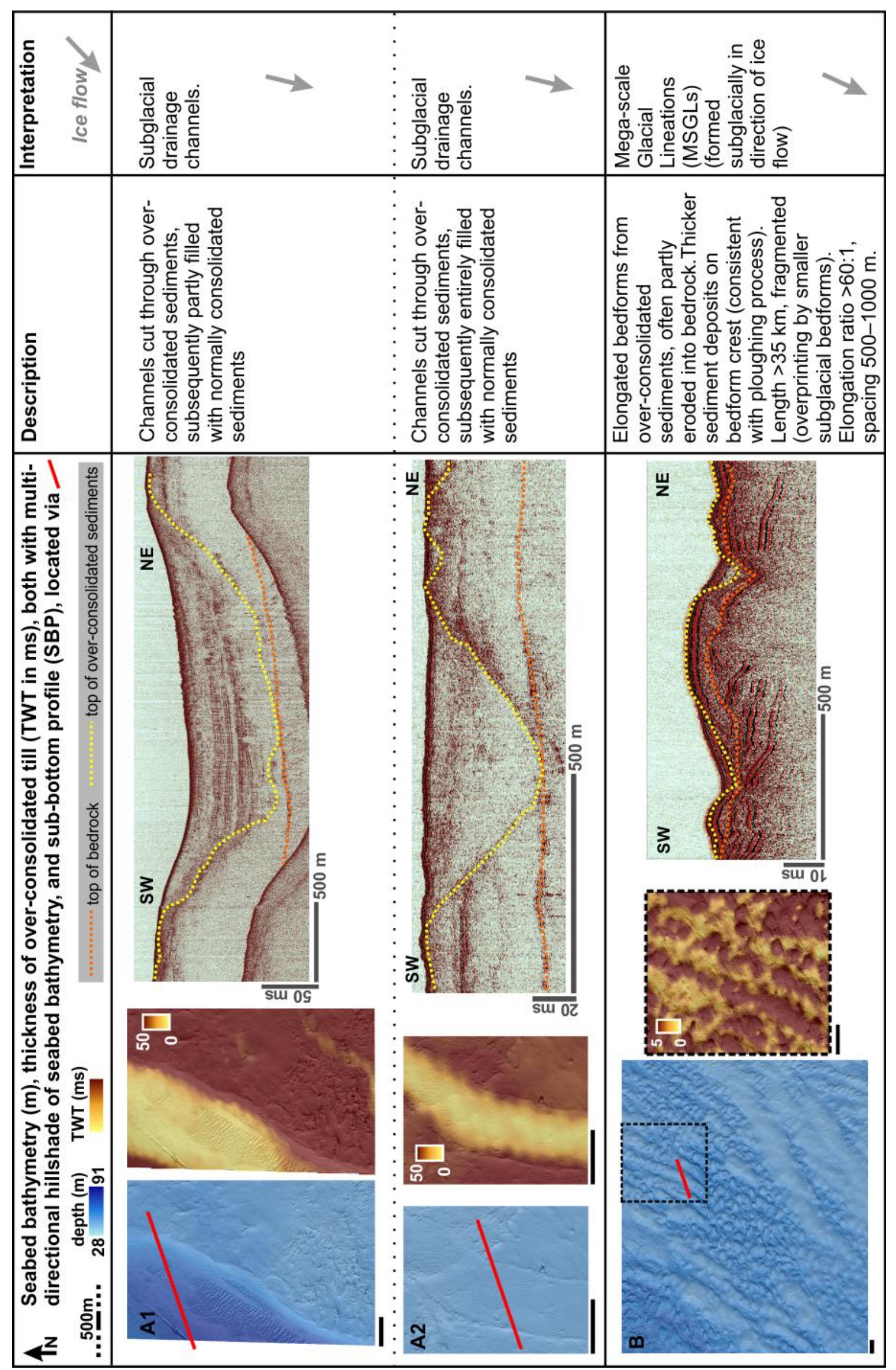




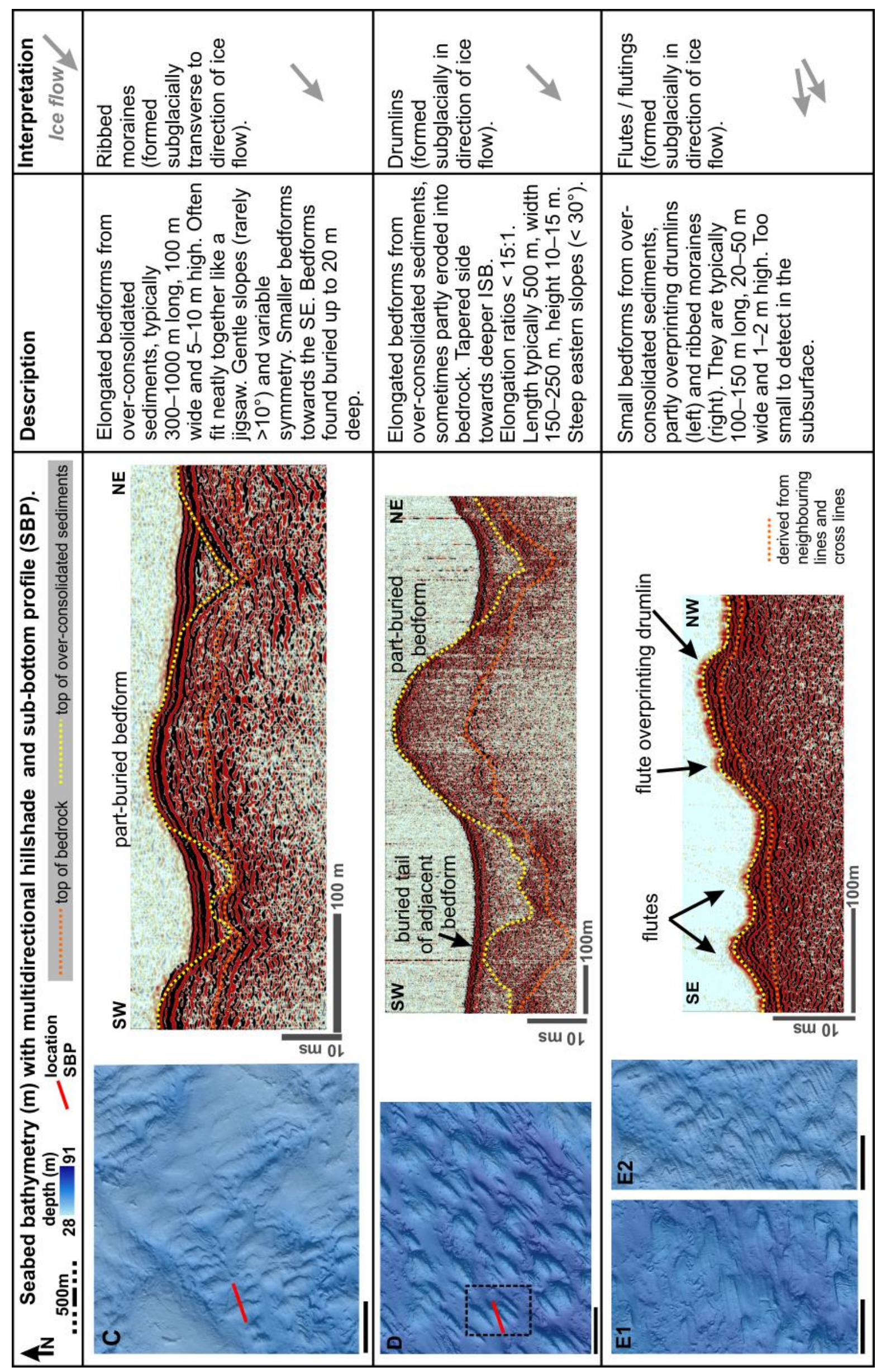




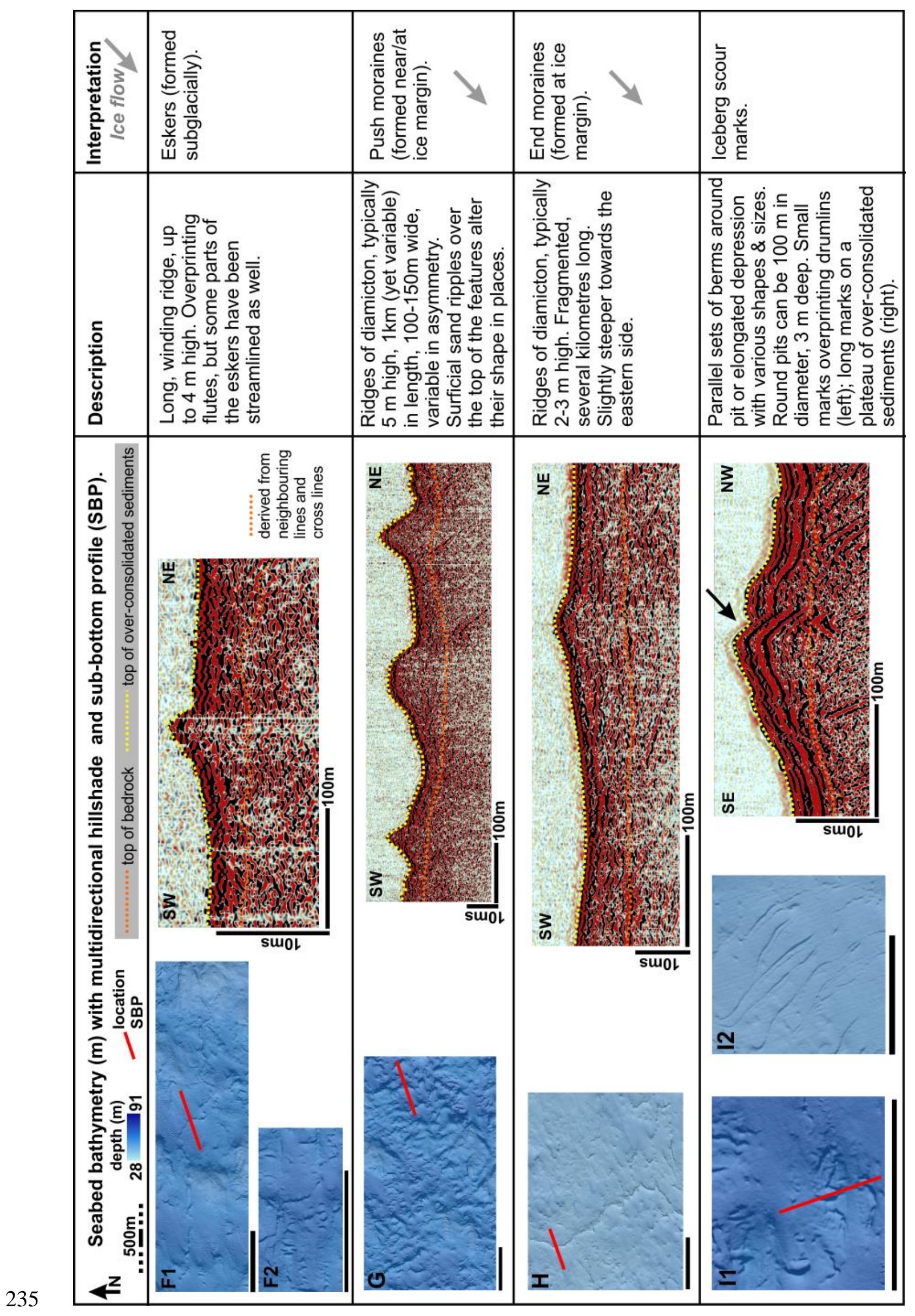


236 Figure 4. Three panels with examples (A-I) of bedforms identified in the multibeam

237 echosounder data and sub-bottom profiles (SBP), with delineation of bedrock and over-

238 consolidated till surfaces on the acoustic profiles, description and interpretation of the

239 bedforms and the implied direction of ice flow.

241 Figure 5 presents maps of the axes of these individual bedforms identified and exemplified in

242 Fig. 4. Only the axes of the MSGL could be traced into the subsurface from the $500 \times 150 \mathrm{~m}$

243 grid of sub-bottom profiles. The precise axis of individual smaller and (partly) buried

244 bedforms could not be fully delineated from sub-bottom profiles, but their presence could be

245 detected. The ice-flow sets (FS) interpreted from these bedform assemblages are summarised

246 in Fig. 5J and in Fig. 8 and contextualised with the five stages of the advance and retreat

247 chronology for the ISIS defined in Section 1.2. 


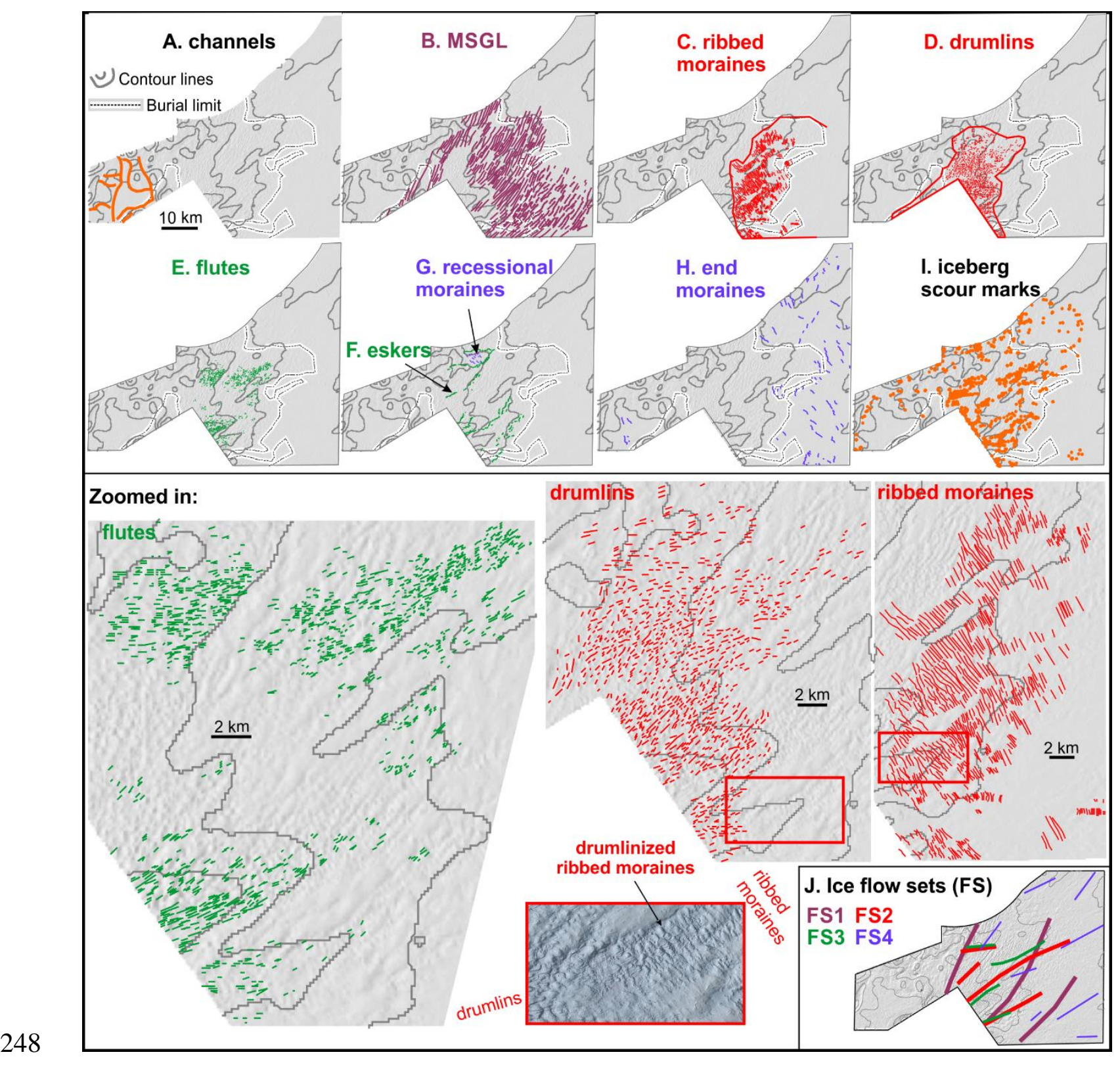

249 Figure 5. A-I: The axes of the individual bedforms as identified and exemplified in the panels

250 of Fig. 4. Only the axes of the MSGL could be digitised from the sub-bottom profiles, so the

251 axes of the ribbed moraines and drumlins only represent the bedforms present on the seabed

252 surface. The areas with all ribbed moraines, drumlins and flutes have been zoomed in to

253 better discern the direction of the longest axes of the bedforms, and a hillshaded seabed

254 bathymetry displays the drumlinised ribbed moraines. J: schematic representation of ice-flow

255 sets (FS) interpreted from these bedform assemblages and their overprinting relationships

256 (Fig. 4). 
3.3 Mega-scale glacial lineations (MSGLs) forming and exposing bedrock - ISIS maximum extent and rapid initial retreat

The western till plateau (Zone 1) comprises over-consolidated tills that are incised by linear channels (Fig. 4A) dissecting in places the entire sedimentary sequence with a similar NNESSW orientation to the subglacial drainage systems on Anglesey (Lee et al., 2015). The channels have been filled partially or fully by normally consolidated sediments, and some infills post-date moraine formation on the plateau, as the crests of some moraines are interrupted across the infilled channels (Fig. 4A). Thick accretionary wedges of normally consolidated glacigenic sediments formed in places at the edge of the till plateau, seemingly fed in part from these incised channels. This plateau of till has been eroded and the eroded sediments moulded into a series of subglacial bedforms (Fig. 6), creating the central glacial terrain with subglacial bedforms on the seabed surface (Zone 2).

Forming Flow Set (FS) 1, large-scale ridges of >30 km long, about 20-25 m high and with elongation ratios approaching 60:1 occur as a broad $45 \mathrm{~km}$ wide swathe across this Zone 2. Interpreted as mega-scale glacial lineations (MSGLs - Fig. 4B; Fig. 6), these bedforms are partly buried by normally consolidated sediments in the east of Zone 2 and their sizes compare well with reported MSGL (Spagnolo et al., 2014). The integration of BH 32a and BH33 with the sub-bottom profile over an MSGL exemplifies the differences in sediment properties between the MSGL crest and trough (Fig. 2; 6), with over-consolidated gravelly sands and clays forming the MSGL crest, and mainly normally consolidated gravelly clays filling in the troughs between MSGLs. Across the large study area the orientation of MSGLs gradually changes. In the northwest and central region of Zone 2, the MGSLs are orientated $205^{\circ}$, parallel to the main axis of the ISB, but curve westerly $240^{\circ}$ moving progressively 
281 southeast (Fig. 5B;6), and thus guided probably by the topography of the island of Anglesey

282 (Phillips et al., 2010 - Fig. 1).


285 Figure 6. Data of the surface and sub-surface expression of mega-scale glacial lineations

286 (MSGLs) from 3D grids of depth to the seabed surface, depth to the over-consolidated till and 
the thickness of the over-consolidated till. The latter was presented with both a linear color gradient and with a stretched classification system using histogram equalisation to enhance contrast across this large study area with large variations in till thickness. Panels A, B and C display 2D seismic profiles perpendicular to the long axis of MSGLs, with a depth scale in

291 Two-Way-Travel Time (TWT). Panel A shows the erosional edge of the subglacial till

292 plateau and subglacial bedforms buried underneath normally consolidated sediments and formed partly erosional into the underlying bedrock. Panels B and C display partly and fully buried subglacial MSGLs constructed from erosion into bedrock and deposition of till.

A key interpretation integrated from the analysis of $16500 \mathrm{~km}$ of sub-bottom profiles, is that the swathe of MSGLs is flanked to the west, north and east by the remaining plateau of overconsolidated till and that the MSGLs have interspaced grooves that incise into the bedrock (Fig. 6), creating lower-amplitude MSGL in the bedrock surface over which overconsolidated till was deposited (Fig. 2;6). No meltwater-related deposits were observed onlapping the over-consolidated sediments in the MSGLs and the bedrock in between the MSGLs is overlain by a very thin layer of over-consolidated till, or directly by normally consolidated sediments. There is thus no evidence for bedforms to have formed via subglacial floods, and the MSGLs were seemingly formed via subglacial erosion into bedrock and deposition of till. The bedrock, predominantly Carboniferous sand stones, siltstones and mudstones in this area, was thus eroded into and left temporarily exposed as part of the

307 subglacial bed due to MSGL formation. This erosional phase of ice streaming has an ISIS

308 axis-parallel alignment. To sustain ice flow parallel to the axis of the ISIS on the seafloor and across Anglesey (Phillips et al., 2010) requires an ice front significantly to the south of the constriction between Wicklow and the Llŷn Peninsula. This erosional phase is therefore associated with geochronological Stages 1 and 2, during extension to maximum limits and/or 
312 with ice streaming during the initial rapid retreat (27-25 ka BP) (Praeg et al., 2015; Scourse

313 et al., 2019; Smedley et al., 2017b, Small et al., 2018).

\section{3.4 Frozen bed and onset of warm-based ice streaming}

315 Fields of moraines (Fig. 4C) in the central Irish Sea Basin with often jigsaw-puzzle

316 arrangements have been interpreted as ribbed moraines (Van Landeghem et al., 2009), with a

317 formation mechanism of brittle fracture of frozen till aligned with that proposed by Kleman

318 and Hättestrand (1999). These ribbed moraines gradually evolve down-ice where moraines

319 start having a clearly tapered side interpreted as drumlins (Fig. 4D; Van Landeghem et al.,

320 2009), and can be explained by time and space transgressive model by Kleman and

321 Hättestrand (1999) where this transition occurs due to a phase change of frozen bed to thawed

322 bed. The data presented here, show that ribbed moraines and drumlins overprint the MSGL

323 terrain (Fig. 3; 5B-D). The ribbed moraines are transversely orientated to a $225-255^{\circ} \mathrm{N}$ ice

324 flow and display evidence for topographical focusing of ice flow as the long axes of ribbed

325 moraines are transverse to ice flow direction, and these axes broadly follow the contour lines

326 of the background bathymetry (Fig. 5C). Identical ice flow alignment is displayed by the

327 drumlins, elongated parallel to the ice flow direction, and together with the ribbed moraines

328 they form FS2. The area of drumlinised ribbed moraines between the ribbed moraine and

329 drumlin field (Fig. 5; Van Landeghem et al., 2009) reflects time-transgressive changes to a

330 lubricated and less rigid bed rheology (cf. Kleman and Hättestrand, 1999). Towards the

331 western steeper slopes of Zone 2, drumlin elongation ratios increase from <1.5:1 to 5:1 and

332 the converging directions of the long drumlin axes are indicative of a convergence of south-

333 westerly ice flows guided by the topography. To the east and south-east of Zone 2 the glacial

334 landscape is buried (Zone 3), and MSGLs, ribbed moraines and drumlins are visible in the

335 sub-bottom acoustic data (Fig. 4C; 4D). Both drumlins and ribbed moraines display an ice-

336 flow alignment more in keeping with geochronological Stage 3. This westerly - south- 
westerly ice flow alignment corresponds with short-lived stabilisations of the ice margin at the constriction of the Irish Sea between Wicklow and Llŷn Peninsula at $22.6 \pm 1$ ka BP (Small et al., 2018; Smedley et al., 2017a), draw-down of the ice surface, greater topographical focusing and the inception of ice-free marine conditions in the western ISB

341 (Chiverrell et al., 2018).

\subsection{Ice flows into ice-free western ISB}

343 Smaller bedforms overprint and have moulded locally all the previous ice-flow sets and are

344 interpreted as flutes or flutings (Fig. 4E). The numerous lineations vary from a westerly

345 direction on flat seabed to a south-westerly direction where they are conditioned by and

346 follow the seabed topography (FS3 - Fig. 5E). The flutings often overprint multiple bedforms

347 (e.g. drumlins and ribbed moraines) and their dimensions of $\sim 60 \mathrm{~m}$ wide and $1500 \mathrm{~m}$ long

348 approach those of mega-flutes (Bluemle et al., 1993). Formation of such elongated flutings

349 are primarily associated with a temperate and grounded glacial land-system (Evans and

350 Twigg, 2002; Stokes and Clark, 2002) and have been linked with surge type ice flow

351 behaviour and high basal ice velocities (Bluemle et al., 1993; Waller et al., 2008).

352 Our interpretation of flow sets 2 and 3 (ribbed moraines, drumlins and flutes), is that a phase

353 of reduced ice streaming allowed frozen bed conditions and ribbed moraines to form. A

354 resumption of warm-based ice streaming cased the drumlinisation of the ribbed moraines as

355 the thawing front moved eastwards. The subsequent ice flow surge stopped the thawing front

356 migrating eastwards and resulted in flutings over the top of drumlins and the most westerly

357 ribbed moraines. The ice margin then lifted off temporarily to preserve the remaining ribbed

358 moraines from further subglacial reworking.

359 Eskers are also preserved well in Zone 2 and their direction is seemingly controlled by the 360 changes in topography (Fig. 4F; 5F). Their spacing varies between 2 and $8 \mathrm{~km}$ and their 
general direction aligns with the ice flow directions derived from FS2 (ribbed moraines and drumlins). They are found mostly superimposed on FS1-3 (MSGLs, ribbed moraines,

363 drumlins and flutes) (Fig. 5F), but occasionally are moulded into flutes and so may be

364 contemporary with the end of FS3 (Fig. 4F2). As the eskers align with ice flow directions, we

365 favour esker formation by a time-transgressive build-up of sediment beneath a more slowly

366 retreating ISIS margin as opposed to instantaneous formation due to large meltwater floods,

367 which would see more frequent eskers in a larger range of directions (Hewitt, 2011).

368 Glacifluvial bedforms and associated sediments are sparsely distributed in Zone 2, limited to

369 these confined englacial/subglacial tunnels systems and isolated large depositional forms.

370 These forms include subaqueous fans formed against topographic highs that provided pinning

371 points for probably short-lived grounding-line stabilisation (Fig. 7). The restricted nature of

372 outwash deposits prevented potentially the burial of the glacial landscape of Zone 2. This

373 phase of warm-based ice streaming requires an ice-free western ISB, and is most likely

374 associated with the transition from geochronological Stage 3 to 4 , between $21.4 \pm 1.0 \mathrm{ka}$ and

$37519.8 \pm 0.8 \mathrm{ka}$ BP during which the western and deeper (100-140 $\mathrm{m} \mathrm{bmsl})$ ISB had

376 deglaciated (Ballantyne and Ó Cofaigh, 2017; Chiverrell et al., 2018; McCabe, 2008).

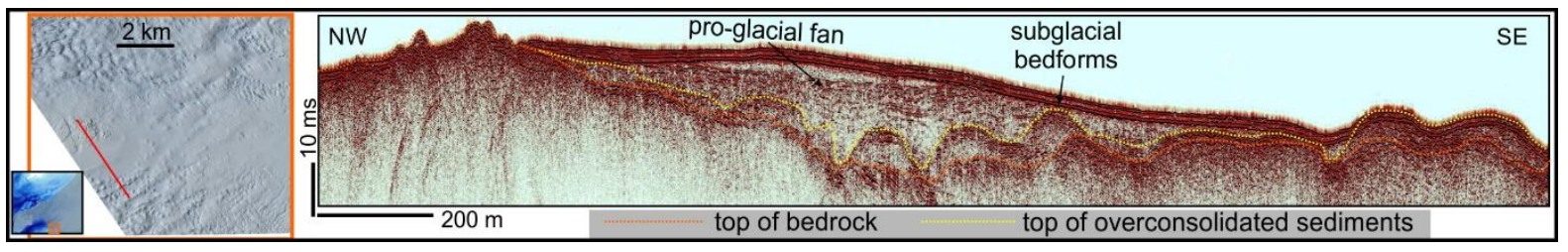

379 Figure 7. A fan of proglacial sediments deposited down-ice from a bedrock outcrop.

380 The subglacial bedforms buried by the proglacial sediments were constructed by erosion into

381 bedrock and deposition of till. 


\subsection{Ice margin retreat towards east and northeast}

384 Small ice-flow transverse ridges in a lobate planform overprint FS1-3 in the north of Zone 2

385 (Fig. 4G; 5G). Typically $5 \mathrm{~m}$ in height, 100-150 $\mathrm{m}$ in width and about $1 \mathrm{~km}$ long, these

386 regularly-spaced ridges are often broken up, but can be interpreted as ice marginal or

387 recessional moraines formed by small-scale oscillations of a retreating lobate ice margin. The

388 recessional moraines were the last grounded bedforms created in the area, with few flutes

389 discernible and probably reworked by moraine formation during retreat characterised by

390 backstepping and minor re-advances of the ice margin. Zones 1 and 2 are densely overprinted

391 by numerous well-preserved iceberg pits and elongated scour marks (Fig. 4I; Van

392 Landeghem et al., 2009), suggesting the generation of large numbers of icebergs and the

393 possible collapse of the ice stream in a subaqueous environment (Van Landeghem et al.,

394 2009). The eastern extent of the iceberg scour field coincides with a break in the background

395 topographic slope of the region at 40-50 m water depths, in turn matching the burial limits of

396 the glaciated terrain (Fig. 1B; 5I). A series of long moraines in Zone 4 (Fig. 1B; 4H;5H) are

397 interpreted as ice-front moraines formed parallel to the retreating ice margins. This last phase

398 of ice retreat is attributed here to geochronological Stages 4-5, and retreat of the ice margin

399 across the shallower (50-20 m bmsl) eastern ISB moving north across the Isle of Man

400 between $20.7 \pm 0.7$ and $19.3 \pm 0.8 \mathrm{ka} \mathrm{BP}$ (Chiverrell et al., 2018).

401

\section{4. DISCUSSION}

$403 \quad$ 4.1 Changing ice flow dynamics with evolution of the Irish Sea Ice Stream

404 The evolution of the ISIS from 27 to $18 \mathrm{ka} \mathrm{BP}$ is described here in five chronological stages

405 (Section 1.2, and all the references herein). The ice-flow sets (FS) interpreted from glacial

406 bedform assemblages (Fig. 5J) are organised chronologically in Fig. 8E-I, contextualised 
with these five stages of the advance and retreat. Ice flow is evidenced in Stage 1 (27-25 ka BP) by large-scale MSGL (FS1 - Fig. 8A), providing the first definitive subglacial bedform evidence for ice streaming within, and axis-parallel to, the ISB, and thus attributed to ice margins located south of the Llŷn Peninsula - Wicklow constriction (Fig. 8F). Channelised meltwater floods created large and deep tunnel valleys in Zone 1, at a time when meltwater production under the ISIS potentially increased as ice flow was faster. The dataset presented here shows two components to MSGL formation: subglacial erosion and till deformation.

414 During ISIS advance, bedrock erosion resulted in grooves and low-amplitude MSGLs,

415 leaving bedrock exposed on the ice-bed interface. A second and less erosive component to

416 MSGL formation left deformable till redistributed and deposited as crests of the MSGLs.

417 These two components must have occurred within the same flow phase as the MSGL grooves 418 align perfectly with the crests. The FS1 flow alignment and long MSGLs favour formation by 419 discharge of an ice stream thick enough to generate this erosion (cf. Motyka et al., 2006) and to reach the Celtic Sea (e.g. Praeg et al., 2015; Lockhart et al., 2018 - Fig. 8F), at net advance rates of $\sim 350 \mathrm{~m} \mathrm{a}^{-1}$ (Smedley et al., 2017a). MSGL formation probably continued during the early phases of margin retreat (Stage 2), but then a significant change occurs. Analyses of FS2 reveals a $20^{\circ}$ and $60^{\circ}$ change in ice flow direction, and formation of ribbed moraines implies a slow-down in ice flow as they form in the ice stream onset zone where the bed is frozen (e.g. Kleman and Hättestrand, 1999). At the end of Stage 3, ice margins retreated and stabilised north of the Wicklow-Llŷn limit during early Stage 4, developing westerly ice flow trajectories and oscillatory dynamics of the ice margin (Smedley et al., 2017a; Thomas and

428 Chiverrell, 2007), conditions that are consistent with observations from FS2 (Fig. 8b; 8G). The drumlinisation has an erosional component carving into the bedrock surface (Fig. 4C; 7)

430 and delineates the onset of warm-based ice streaming in FS2. As Zone 2 is progressively 431 drumlinised (Fig. 5), faster ice was flowing (c.f. King et al., 2016; Smith and Murray, 2009) 
432 from the shallow Zone 4 (Fig. 1B) towards accommodation space growing in the western ISB

433 (end of Stage 3). Drumlinisation was encouraged by the preceding ice stagnation during

434 ribbed moraine formation and the associated ice thickening providing sufficient frictional

435 heat to potentially melt basal ice and for the renewed ice streaming to deform the stiffer basal

436 diamictons. The timing of Stages 3 and $4(22.6 \pm 1$ to $20.7 \pm 0.7 \mathrm{ka} \mathrm{BP})$ overlaps with cool

437 conditions in the North Atlantic (Rasmussen et al., 2014) and thermodynamic glacial

438 processes are thus favoured as the main driver for this flow-reactivation. This is an important

439 consideration in understanding present-day ice stream behaviour, as ice flow shut down and

440 abrupt changes in ice flow directions are observed and predicted to occur more frequently for

441 Antarctic ice streams (c.f. Conway et al., 2002). Fluting reflects a later realignment and last

442 phase of faster ice flow (FS3) at the start of Stage 4, which is attributed to ice surging into

443 deep waters to the west (Fig. 8C; 8H). The end of the fluting phase is associated with a

444 lubricated subglacial environment and extensive drainage patterns, with extensive iceberg

445 calving. The collapse of the ice stream was imminent with ice margin retreat patterns

446 seemingly topographically conditioned as small recessional moraines and large end-moraines

447 formed in a direction consistent with ice pulling back towards the Isle of Man and NW

448 England (Fig. 8D; 8I).

449 Sectors of the MSGL and ribbed moraine terrain were not drumlinised and we attribute this to 450 temporary lift-off of the ice bed in those areas driven by ice thinning due to intense iceberg

451 calving rather than sea level rise, which was probably limited over the estimated time of

452 grounding line fluctuations. Where the ice margin grounded again at the top of the break in 453 regional slope, it stagnated, with restricted calving and prolonged subglacial meltwater

454 drainage providing sediments to bury the eastern edge of the glacial terrain. Burial may have 455 continued during Stage 5, when Scottish ice re-advanced towards the northern edge of the 456 study area (Fig. 8D; 8I). 

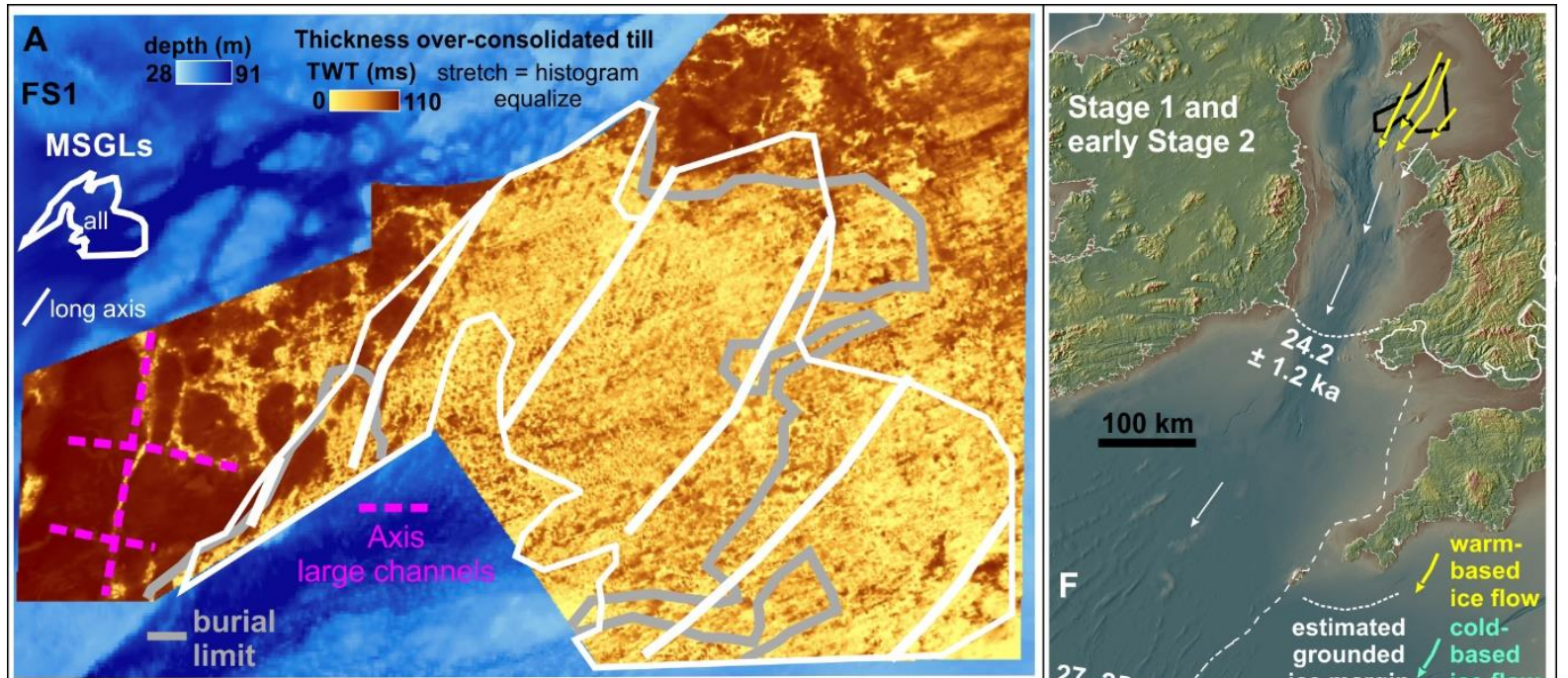

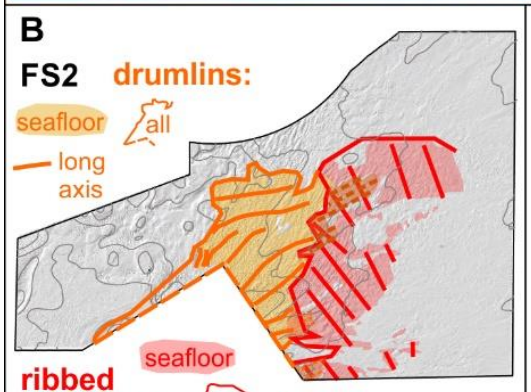

moraines: all Jlong axis flutes: seafloor

...- drumlinized ribbed moraines

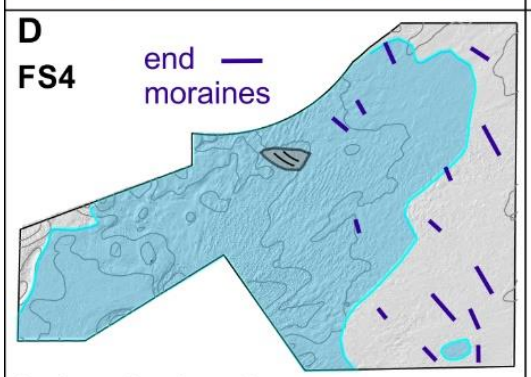

iceberg keel marks:

recessional moraines: seafloor \axis

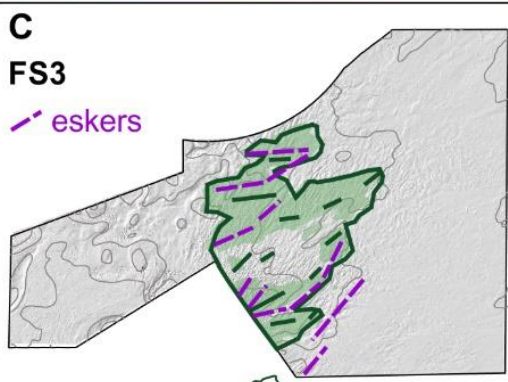

flutes: seafloor all -long axis

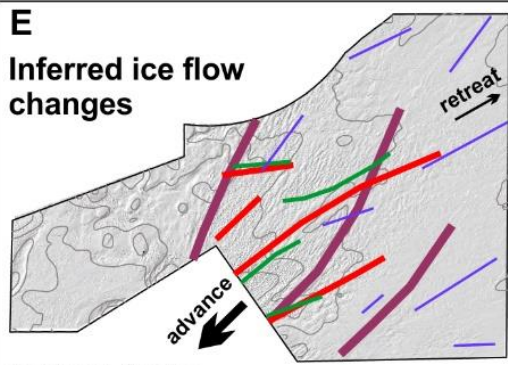

derived from:

FS1 $>$ FS2 $>$ FS3 $>$ FS4
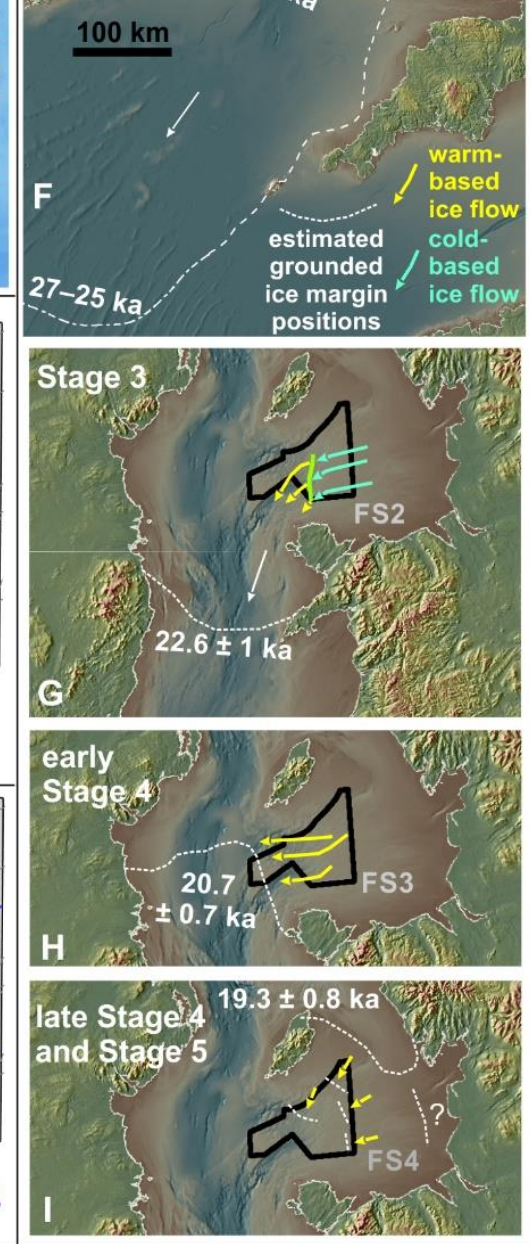

459 Figure 8. Summary geomorphology with Flow Sets (FS1-3) represented schematically. Panel

460 (A) shows FS1 on over-consolidated glacigenic sediment thickness data in Two-Way-Travel

461 Time (TWT) and with a stretched classification system using histogram equalisation to

462 enhance contrast. Panels (B-E) display Flow Sets on contoured present-day seabed

463 topography (see Fig. 1B). Panels F-I contextualises the temporal and spatial evolution of the

464 palaeo-glacial landscape in the studied area (outlined in black) with the published 
geochronology for the retreat of the former ISIS (see Section 1.2) to visualise the changes in ice flow dynamics.

\subsection{Geological factors regulating ice sheet drainage?}

469 Our qualitative observations of changing bed conditions provide an insight into the link

470 between ice streaming and subglacial geological factors. Regional-scale erosion occurred into 471 the original till plateau and into the bedrock during formation of meltwater flow channels in 472 Zone 1 and the $>30 \mathrm{~km}$ long MSGLs in Zone 2. In Zone 2, the deformable sediments were 473 largely removed where MSGLs were formed. This is evidenced through the integrated 474 interpretation of $16500 \mathrm{~km}$ of individual sub-bottom geophysical profiles (Fig. 4; 6; 8), where 475 the interpretation of the base of the over-consolidated glacigenic sediments (as gridded from 476 the seismic horizons) show clearly that the swathe of MSGLs is flanked to the west, north 477 and east by the remaining plateaus of over-consolidated till (Fig. 6; 8), where the deviated ice 478 flow path around the Isle of Man was likely most erosive in the immediate pathway of the deviation. This pervasive erosional character in Stages 1 and 2 of ISIS advance and the initial

480 retreat agrees with observations beneath contemporary (Jezek et al., 2011) and palaeo-ice 481 streams with limited deformable sediment at the ice-bed (e.g. Bradwell, 2013; Krabbendam et al., 2016; Smith, 1948). We suggest that the erosional processes involved during fast ice streaming in the ISB induced a change in the geological factors steering the ice streaming, as after the near complete removal of a deformable substrate from Zone 2, the bedrock became exposed under the ice. These changes in ice-bed conditions would have adjusted ISIS dynamics internally, as the style of basal sliding and subglacial drainage changes when the bedrock underneath the eroded till is reached. Increased basal drag can slow down ice flows and trigger basal freezing (c.f. Jacobson and Raymond, 1998). This may have happened to the 
490 to form. Passage of the ice margins northwards of the constriction between Wicklow and the

491 Llŷn Peninsula may also have contributed towards a slow-down in ice stream velocity. When

492 the downstream end of the retreating ISIS reached this area of exposed bedrock, the ice flow

493 changed direction with ribbed moraines and drumlins (FS2). The change from fast flow over

494 warm-based water-saturated soft diamictons, to a temporarily compressional, re-aligned and

495 slower flow over cold-based and stiffer basal diamict is a significant change in ice stream

496 dynamics. These observations from the palaeo-ISIS agree with a recent sensitivity analyses in

497 ice stream models, finding changes in basal friction particularly influential for ice stream

498 dynamics when these changes are felt near the grounding zone (Alley et al., 2019). In our

499 case study, where the retreating palaeo-ISIS experienced topographical confinement and

500 where the western ISB started to become ice free, we propose that the changes in basal

501 friction will have been an additional contributing factor in ice stream shut-down, ice flow re-

502 alignment and ultimate demise.

\section{5. CONCLUSION}

505 The evolution of a well-preserved glacial landscape in the central part of a large palaeo-ice

506 stream details changes in ice flow dynamics during its advance and retreat that parallel

507 changes in ice thickness, ice bed conditions and proglacial open water accommodation space.

508 This reconstruction, linked to the robust geochronology of ice margin retreat, reveals that the

509 erosive ice stream processes exposed the bedrock underneath the ice during ice advance

510 and/or the early phases of deglaciation as MSGLs were formed via an erosive and subsequent

511 depositional component within one ice-flow phase. We propose that the changes in basal

512 friction due to bedrock exposure to the ice may have contributed to defining the nature of

513 dynamics during deglaciation through slower ice flow velocities and basal freezing. During

514 later phases of deglaciation, topographic variations in the subglacial bed near the grounding 
515 line increasingly conditioned ice flow as re-activation and re-alignment of ice streaming led to an ultimate demise. This new analysis highlights that ice streaming can be determined by

517 how ice flow impacts local geology both prior to and during deglaciation, by altering the

518 availability of deformable bed and bed roughness underneath the ice. The dynamics of a

519 rapidly retreating palaeo-ice streams can thus be steered by the processes prior to the final

520 retreat phase, identifying a need for detailed parametrisation of ice-bed conditions throughout

521 all flow phases when forecasting episodes of changing retreat rate, shutdown and reactivation

522 of present-day ice streams, still the least understood components of ice sheet dynamics.

\section{AKNOWLEDGMENTS}

525 The Crown Estate, a manager of the UK seabed, has published this offshore data on its online

526 Marine Data Exchange. This data has been gathered from surveys and technical studies from

527 the former Celtic Array offshore wind project off the coast of Anglesey in Wales, UK. Van

528 Landeghem acknowledges the financial support provided by the Welsh Government and

529 Higher Education Funding Council for Wales through the Sêr Cymru National Research

530 Network for Low Carbon, Energy and Environment.

531 The discussions with the reviewers have been a valuable contribution to this work, for which

532 the authors are grateful.

\section{REFERENCES}

Alley, R.B., Li, W., Parizek, B.R., Zhang, F., 2019. Evaluation of ice-stream model sensitivities for parameter estimation. Earth and Planetary Science Letters 516, 49-55

Ballantyne, C.K., Ó Cofaigh, C., 2017. The last Irish Ice Sheet: extent and chronology, 
Bamber, J.L., Vaughan, D.G., Joughin, I., 2000. Widespread complex flow in the interior of the Antarctic Ice Sheet. Science 287(5456), 1248-1250.

Bluemle, J.P., Lord, M.L. and Hunke, N.T., 1993. Exceptionally long, narrow drumlins formed in subglacial cavities, North Dakota. Boreas 22(1), 15-24.

Bradley, S.L., Milne, G.A., Shennan, I. and Edwards, R., 2011. An improved glacial isostatic adjustment model for the British Isles. Journal of Quaternary Science 26(5), 541-552.

Bradwell, T., 2013. Identifying palaeo-ice-stream tributaries on hard beds: Mapping glacial bedforms and erosion zones in NW Scotland. Geomorphology 201, 397-414.

Bradwell, T., Small, D., Fabel, D., Smedley, R.K., Clark, C.D., Saher M.H., Callard, S.L., Chiverrell, R.C., Dove, D., Moreton, S.G., Roberts, D.H., Duller, G.A.T. and Ó Cofaigh, C., 2019. Ice-stream demise dynamically conditioned by trough shape and bed strength. Science Advances 5 (4).

Chiverrell, R.C., Smedley, R.K., Small, D., Ballantyne, C.K., Burke, M.J., Callard, S.L., Clark, C.D., Duller, G.A.T., Evans, D.J.A., Fabel, D., Van Landeghem, K., Livingstone, S., Ó Cofaigh, C., Thomas, G.S.P., Roberts, D.H., Saher, M., Scourse, J.D. and Wilson, P., 2018. Ice margin oscillations during deglaciation of the northern Irish Sea Basin. Journal of Quaternary Science 33(7), 739-762.

Chiverrell, R.C., Thrasher, I.M., Thomas, G.S.P., Lang, A., Scourse, J.D., Van Landeghem, K.J.J., McCarroll, D., Clark, C.D., Ó'Cofaigh, C., Evans, D.J.A. and Ballantyne, C.K., 2013. Bayesian modelling the retreat of the Irish Sea Ice Stream. Journal of Quaternary Science 28(2), 200-209.

Conway, H., Catania, G., Raymond, C.F., Gades, A.M., Scambos, T.A. and Engelhardt, H., 2002. Switch of flow direction in an Antarctic ice stream. Nature 419(6906), 465467. 
563 Cuffey, K.M., Conway, H., Gades, A., Hallet, B., Raymond, C.F. and Whitlow, S., 2000. Deformation properties of subfreezing glacier ice: Role of crystal size, chemical impurities, and rock particles inferred from in situ measurements. Journal of Geophysical Research-Solid Earth 105(B12), 27895-27915.

Evans, D.J.A. and Twigg, D.R., 2002. The active temperate glacial landsystem: A model based on Breiðamerkurjökull and Fjallsjökull, Iceland. Quaternary Science Reviews 21(20-22), 2143-2177.

Hewitt, I.J., 2011. Modelling distributed and channelized subglacial drainage: The spacing of channels. Journal of Glaciology 57(202), 302-314.

Hindmarsh, R.C.A., 2018. Ice Sheet and Glacier Modelling, Past Glacial Environments, pp. $605-661$.

Hogan, K.A., Dowdeswell, J.A., Noormets, R., Evans, J. and Ó'Cofaigh, C., 2010. Evidence for full-glacial flow and retreat of the Late Weichselian Ice Sheet from the waters around Kong Karls Land, eastern Svalbard. Quaternary Science Reviews 29(25-26), $3563-3582$.

Jacobson, H.P. and Raymond, C.F., 1998. Thermal effects on the location of ice stream margins. Journal of Geophysical Research: Solid Earth 103(6), 12111-12122.

Jamieson, S.S.R., Vieli, A., Livingstone, S.J., Cofaigh, C.Ó., Stokes, C., Hillenbrand, C.D. and Dowdeswell, J.A., 2012. Ice-stream stability on a reverse bed slope. Nature Geoscience 5(11), 799-802.

Jamieson, S.S.R., Stokes, C.R., Livingstone, S.J., Vieli, A., Ó Cofaigh, C., Hillenbrand, C-D and Spagnolo, M., 2016. Subglacial processes on an Antarctic ice stream bed. 2: Can modelled ice dynamics explain the morphology of mega-scale glacial lineations? Journal of Glaciology 62(232), 285-298 
Jezek, K., Wu, X., Gogineni, P., Rodríguez, E., Freeman, A., Rodriguez-Morales, F. and Clark, C.D., 2011. Radar images of the bed of the Greenland Ice Sheet. Geophysical Research Letters 38(1), https://doi.org/10.1029/2010GL045519.

King, E.C., Hindmarsh, R.C.A. and Stokes, C.R., 2009. Formation of mega-scale glacial lineations observed beneath a West Antarctic ice stream. Nature Geoscience 2(8), $585-588$.

King, E.C., Pritchard, H.D. and Smith, A.M., 2016. Subglacial landforms beneath Rutford Ice Stream, Antarctica: detailed bed topography from ice-penetrating radar. Earth System Science Data 8(1), 151-158.

Kleman, J. and Applegate, P.J., 2014. Durations and propagation patterns of ice sheet instability events. Quaternary Science Reviews 92, 32-39.

Kleman, J. and Glasser, N.F., 2007. The subglacial thermal organisation (STO) of ice sheets. Quaternary Science Reviews 26(5-6), 585-597.

Kleman, J. and Hättestrand, C., 1999. Frozen-bed Fennoscandian and Laurentide ice sheets during the Last Glacial Maximum. Nature 402(6757), 63-66.

Kleman, J., Hättestrand, C., Stroeven, A.P., Jansson, K.N., De Angelis, H. and Borgström, I., 2006. Reconstruction of Palaeo-Ice Sheets-Inversion of their Glacial Geomorphological Record. In: P.G. Knight (Editor), Glacier science and environmental change. Blackwell Publishing, Malden, USA, pp. 192-198.

Krabbendam, M., Eyles, N., Putkinen, N., Bradwell, T. and Arbelaez-Moreno, L., 2016. Streamlined hard beds formed by palaeo-ice streams: A review. Sedimentary Geology 338, 24-50. 
609 Kurjanski, B., Rea, B.R., Spagnolo, M., Winsborrow, M., Cornwell, D.G., Andreassen , K., 610 Howell, J., 2019. Morphological evidence for marine ice stream shutdown, central 611 Barents Sea. Marine Geology 414, 64-76

612 Lakeman, T.R., Pienkowski, A.J., Nixon, F.C., Furze, M.F.A., Blasco, S., Andrews, J.T. and 613 King, E.L., 2018. Collapse of a marine-based ice stream during the early Younger 614 Dryas chronozone, western Canadian Arctic. Geology 46(3), 211-214.

615 Landvik, J.Y., Alexanderson, H., Henriksen, M. and Ingolfsson, O., 2014. Landscape 616 imprints of changing glacial regimes during ice-sheet build-up and decay: a

Lee, J.R., Wakefield, O.J.W., Phillips, E. and Hughes, L., 2015. Sedimentary and structural conceptual model from Svalbard. Quaternary Science Reviews 92, 258-268.

Lockhart, E.A., Scourse, J.D., Praeg, D., Van Landeghem, K.J.J., Mellett, C., Saher, M., Callard, L., Chiverrell, R., Benetti, S., Ó Cofaigh, C. and Clark, C.D. (2018). A stratigraphic investigation of the Celtic Sea megaridges based on seismic and core data from the Irish-UK sectors. Quaternary Science Reviews, 198, 156-170.

McCabe, A.M., 2008. Glacial geology and geomorphology: the landscapes of Ireland. Dunedin Academic Press, Edinburgh, 274 pp.

Motyka, R.J., Truffer, M., Kuriger, E.M., Bucki, K, 2006. Rapid erosion of soft sediments by 629 tidewater glacier advance: Taku Glacier, Alaska, USA, Geophys. Res. Lett. 33, L24504, doi:10.1029/2006GL028467. 
Phillips, E., Everest, J. and Diaz-Doce, D., 2010. Bedrock controls on subglacial landform distribution and geomorphological processes: Evidence from the Late Devensian Irish Sea Ice Stream. Sedimentary Geology 232(3-4), 98-118.

Praeg, D., McCarron, S., Dove, D., Ó Cofaigh, C., Scott, G., Monteys, X., Facchin, L., Romeo, R. and Coxon, P., 2015. Ice sheet extension to the Celtic Sea shelf edge at the Last Glacial Maximum. Quaternary Science Reviews 111, 107-112.

Rasmussen, S.O., Bigler, M., Blockley, S.P., Blunier, T., Buchardt, S.L., Clausen, H.B., Cvijanovic, I., Dahl-Jensen, D., Johnsen, S.J., Fischer, H., Gkinis, V., Guillevic, M., Hoek, W.Z., Lowe, J.J., Pedro, J.B., Popp, T., Seierstad, I.K., Steffensen, J.P., Svensson, A.M., Vallelonga, P., Vinther, B.M., Walker, M.J.C., Wheatley, J.J. and Winstrup, M., 2014. A stratigraphic framework for abrupt climatic changes during the Last Glacial period based on three synchronized Greenland ice-core records: Refining and extending the INTIMATE event stratigraphy. Quaternary Science Reviews 106, $14-28$.

Rignot, E., Mouginot, J., Morlighem, M., Seroussi, H. and Scheuchl, B., 2014. Widespread, rapid grounding line retreat of Pine Island, Thwaites, Smith, and Kohler glaciers, West Antarctica, from 1992 to 2011. Geophysical Research Letters 41(10), 35023509.

Schoof, C. and Hewitt, I.J., 2016. A model for polythermal ice incorporating gravity-driven moisture transport. Journal of Fluid Mechanics 797, 504-535.

Scourse, J., Saher, M., Van Landeghem, K., Lockhart, E.A., Purcell, C., Callard, L., Roseby, Z., Allinson, B., Pienkowski, A.J., O Cofaigh, C., Praeg, D., Chiverrell, R.C., Moreton, S.G., Fabel, D. and Clark, C.D., 2019. Advance and retreat of the marine- 
terminating Irish Sea Ice Stream into the Celtic Sea during the last glacial: timing and maximum. Marine Geology 412, 53-68.

Small, D., Smedley, R.K., Chiverrell, R.C., Scourse, J.D., Cofaigh, C., Duller, G.A.T., McCarron, S., Burke, M.J., Evans, D.J., Fabel, D., Gheorghiu, D.M., Thomas, G.S.P., Xu, S. and Clark, C.D., 2018. Trough geometry was a greater influence than climateocean forcing in regulating retreat of the marine-based Irish-Sea Ice Stream. Bulletin of the Geological Society of America 130(11-12), 1981-1999.

Smedley, R.K., Chiverrell, R.C., Ballantyne, C.K., Burke, M.J., Clark, C.D., Duller, G.A.T., Fabel, D., McCarroll, D., Scourse, J.D., Small, D. and Thomas, G.S.P., 2017a. Internal dynamics condition centennial-scale oscillations in marinebased ice-stream retreat. Geology 45(9), 787-790.

Smedley, R.K., Scourse, J.D., Small, D., Hiemstra, J.F., Duller, G.A.T., Bateman, M.D., Burke, M.J., Chiverrell, R.C., Clark, C.D., Davies, S.M., Fabel, D., Gheorghiu, D.M., McCarroll, D., Medialdea, A. and Xu, S., 2017b. New age constraints for the limit of the British-Irish Ice Sheet on the Isles of Scilly. Journal of Quaternary Science 32(1), $48-62$.

Smith, A.M., Bentley, C.R., Bingham, R.G. and Jordan, T.A., 2012. Rapid subglacial erosion beneath Pine Island Glacier, West Antarctica. Geophysical Research Letters 39(12).

Smith, A.M. and Murray, T., 2009. Bedform topography and basal conditions beneath a fastflowing West Antarctic ice stream. Quaternary Science Reviews 28(7-8), 584-596.

Smith, A.M., Murray, T., Nicholls, K.W., Makinson, K., Adalgeirsdóttir, G., Behar, A.E. and Vaughan, D.G., 2007. Rapid erosion, drumlin formation, and changing hydrology beneath an Antarctic ice stream. Geology 35(2), 127-130. 
678

679

680

681

682

683

684

685

686

687

688

689

690

691

692

693

694

695

696

697

698

699

700

701

Smith, H.T.U., 1948. Giant glacial grooves in northwest Canada. American Journal of Science 246(8), 503-514.

Spagnolo, M., Clark, C.D., Ely, J.C., Stokes, C.R., Anderson, J.B., Andreassen, K., Graham,A.G.C., King, E.C., 2014. Size, shape and spatial arrangement of mega-scale glacial lineations. Earth Surface Processes and Landforms 39, 1432-1448.

Stokes, C.R., 2018. Geomorphology under ice streams: Moving from form to process. Earth Surface Processes and Landforms 43(1), 85-123.

Stokes, C.R. and Clark, C.D., 2002. Are long subglacial bedforms indicative of fast ice flow? Boreas 31, 239-249.

Stroeven, A.P., Hättestrand, C., Kleman, J., Heyman, J., Fabel, D., Fredin, O., Goodfellow, B.W., Harbor, J.M., Jansen, J.D., Olsen, L., Caffee, M.W., Fink, D., Lundqvist, J., Rosqvist, G.C., Strömberg, B. and Jansson, K.N., 2016. Deglaciation of Fennoscandia. Quaternary Science Reviews 147, 91-121.

Thomas, G.S.P. and Chiverrell, R.C., 2007. Structural and depositional evidence for repeated ice-marginal oscillation along the eastern margin of the Late Devensian Irish Sea Ice Stream. Quaternary Science Reviews 26(19-21), 2375-2405.

Tóth, Z., McCarron, S., Wheeler, A.J., Wenau, S., Davis, S., Lim, A. and Spiess, V., 2020. Geomorphological and seismostratigraphic evidence for multidirectional polyphase glaciation of the northern Celtic Sea. Journal of Quaternary Sciences 35, 465-478.

Van Landeghem, K.J.J., Wheeler, A.J. and Mitchell, N.C., 2009. Seafloor evidence for palaeo-ice streaming and calving of the grounded Irish Sea Ice Stream: Implications for the interpretation of its final deglaciation phase. Boreas 38(1), 111-131.

Waller, R.I., Van Dijk, T.A.G.P. and Knudsen, Ó., 2008. Subglacial bedforms and conditions associated with the 1991 surge of Skeiðarárjökull, Iceland. Boreas 37(2), 179-194. 
702 Ward, S.L., Neill, S.P., Scourse, J.D., Bradley, S.L. and Uehara, K., 2016. Sensitivity of 703 palaeotidal models of the northwest European shelf seas to glacial isostatic adjustment since the Last Glacial Maximum. Quaternary Science Reviews 151, 198-211. 